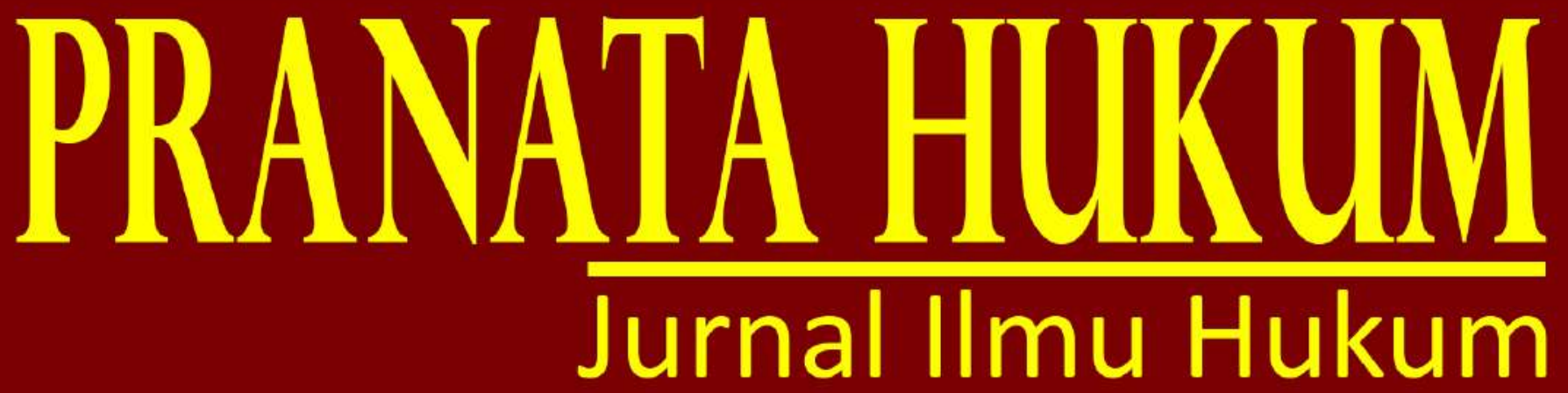

e-ISSN 2685-3213 | p-ISSN 1907-560X

SINERGITAS PEMERINTAHAN DESA DALAM PEMBENTUKAN PERATURAN DESA Anggalana

PENYELESAIAN SENGKETA PERBANKAN BERKAITAN DENGAN PERLINDUNGAN KONSUMEN Dian Herlambang, Muhammad Ridho Wijaya

ANALISIS KOMPARASI ANTARA PERLINDUNGAN PATEN BIASA DENGAN PATEN SEDERHANA BERDASARKAN UNDANG-UNDANG PATEN

Erlina, Melisa Safitri

KONSEPSI NEGARA HUKUM PANCASILA DAN IMPLEMENTASINYA DI INDONESIA Tubagus Muhammad Nasarudin

ANALISIS KEBIJAKAN PEMUNGUTAN RETRIBUSI PELAYANAN PERSAMPAHAN KEBERSIHAN DALAM RANGKA PENINGKATAN PENDAPATAN ASLI DAERAH DI KOTA BANDAR LAMPUNG Pertiwi Agustina RA, Lintje Anna Marpaung, Herlina Ratna Sumbawa Ningrum

ANALISIS KEDUDUKAN PERATURAN DESA PASCA PENGESAHAN UNDANG-UNDANG NOMOR 6 TAHUN 2014 TENTANG DESA DI DESA BADRAN SARI DAN NAMBAH REJO KABUPATEN LAMPUNG TENGAH

Baharudin, Indah Satria, Ramanda Ansori

FANATISME DAN EKSISTENSI NILAI-NILAI DEMOKRASI KADER NAHDLATUL ULAMA KOTA METRO PADA PILPRES 2019

Hendra Irawan, Ika Selviana

PERLINDUNGAN HUKUM TERHADAP PEMENANG LELANG BARANG RAMPASAN NEGARA BERUPA KENDARAAN RODA DUA YANG DIEKSEKUSI DENGAN CARA LELANG OLEH KEJAKSAAN

Okta Vianus Puspa Negara, Zainab Ompu Jainah, S. Tri Herlianto

ANALISIS PERTANGGUNGJAWABAN PELAKU TINDAK PIDANA MENGGANDAKAN SURAT PALSU UNTUK BEKERJA DI PT. GREAT GIANT PINEAPPLE HUMAS JAYA

Helmi Rangkuti, Ketut Seregig, Tami Rusli

MAGISTER HUKUM

UNIVERSITAS BANDAR LAMPUNG

\begin{tabular}{c|c|c|c|l}
$\begin{array}{c}\text { PRANATA } \\
\text { HUKUM }\end{array}$ & $\begin{array}{c}\text { Volume } \\
15\end{array}$ & $\begin{array}{c}\text { Nomor } \\
1\end{array}$ & $\begin{array}{c}\text { Halaman } \\
1-119\end{array}$ & $\begin{array}{l}\text { Bandar } \\
\text { Lampung } \\
\text { Januari } 2020\end{array}$ \\
\hline
\end{tabular}




\section{PRANATA HUKUM}

Jurnal Ilmu Hukum

Magister Hukum

Universitas Bandar Lampung

Terbit Pertama Kali, Juli 2006

Terbit Dua Kali Setahun, Setiap Januari dan Juli

EDITOR IN-CHIEF

Prof. Dr. Lintje Anna Marpaung, S.H., M.H

EDITORIAL BOARDS MEMBERS

Dr. Bambang Hartono, S.H., M.Hum

Dr. Tami Rusli, S.H., M.Hum

Dr. Erlina B, S.H., M.H

Dr. Zainab Ompu Jainah, S.H., M.H

Dr. Zulfi Diane Zaini, S.H., M.H

MANAGING EDITOR

Indah Satria, S.H., M.H

ASSISTANT EDITORS

Yulia Hesti, S.H., MH

Shany Carolina Mawuntu

\section{PENYUNTING AHLI (MITRA BESTARI)}

Prof. Dr. I Gusti Ayu Ketut Rachmi Handayani, S.H., M.M (Universitas Sebelas Maret)

Prof. Dr. I Gede A.B Wiranata, S.H., M.H (Universitas Lampung)

Dr. Nurhadiantomo, S.H., M.Hum (Universitas Muhammdiyah Surakarta)

Dr. Erina Pane, S.H., M.H (UIN Lampung)

\section{Alamat: \\ Kampus B Universitas Bandar Lampung}

Jl. Z.A Pagar Alam No.89 Labuhan Ratu, Bandar Lampung 35142

Telp: 0721-789825 Fax: 0721-770261

Email: jurnal.mh@ubl.ac.id

Jurnal PRANATA HUKUM dimaksudkan sebagai media komunikasi ,edukasi dan informasi ilmiah bidang ilmu hukum. Sajian dan kemasan diupayakan komunikatif melalui bahasa ilmiah.

Redaksi mengundang semua elemen masyarakat ,baik civitas akademika, praktisi , lembaga masyarakat, maupun perorangan yang berminat terhadap bidang hukum untuk berpartisipasi mengembangkan gagasan, wawasan, dan pengetahuan melalui tulisan untuk dimuat dalam jurnal ini. Melalui PRANATA HUKUM diharapkan terjadi proses pengembangan bidang hukum sebagai bagian penting dari rangkaian panjang proses memajukan masyarakat bangsa 


\title{
PERLINDUNGAN HUKUM TERHADAP PEMENANG LELANG BARANG RAMPASAN NEGARA BERUPA KENDARAAN RODA DUA YANG DIEKSEKUSI DENGAN CARA LELANG OLEH KEJAKSAAN
}

\author{
Okta Vianus Puspa Negara, ${ }^{1}$ Zainab Ompu Jainah, ${ }^{2}$ S. Tri Herlianto ${ }^{3}$
}

\begin{abstract}
Prosecutors as law enforcement institutions carry out execution of state loot in various ways, one of which is auctioned for the country. One of the loot state executed by the state attorney of Bandar Lampung by means of auction is a unit of vehicle twowheeled vehicles as contained in the quote treatise Number: 908/2016 issued by the State Wealth Service office and auction of Bandar Lampung. The results of this study showed: (1) The protection of the law against the auction winners of the state booty in the form of two-wheeled vehicles executed by way of auction by the attorney in quotation treatise number: 908/2016 can be realized by enforcing legislation or special policies in order to fulfill the right of auction winners to manage and possess vehicle ownership documents both STNK and BPKB. (2) The legal certainty of the winner of the state Booty auction in the form of a two-wheeled vehicle executed by way of auction by the Prosecutor has not materialized because the auction winner cannot take care of and have the vehicle ownership documents both in the form of STNK The winner of the auction in this case only accepts auction treatise quotes number: 908/2016 which serves as a buy and sell deed.
\end{abstract}

Keywords: legal protection; Auction winners; State loot.

\section{PENDAHULUAN}

Barang rampasan negara merupakan barang bukti kejahatan yang telah memperoleh kekuatan hukum tetap, dirampas untuk negara yang selanjutnya dieksekusi dengan cara dimusnahkan, dilelang untuk negara, diserahkan kepada instansi yang ditetapkan untuk dimanfaatkan dan disimpan di Rupbasan untuk barang bukti dalam perkara atau proses peradilan. ${ }^{4}$ Adanya barang rampasan negara tersebut diawali dengan proses penyitaan oleh aparat penegak hukum, yaitu tindakan hukum berupa pengambilalihan dari penguasaan untuk sementara waktu barang-barang dari tangan seseorang atau kelompok untuk kepentingan penyidikan, penuntutan dan peradilan. Hal ini sesuai dengan ketentuan Pasal 1 butir 16 Kitab Undang-Undang Hukum Acara Pidana (KUHAP) yang menytakan tri.herlianto@ubl.ac.id

${ }^{1}$ Mahasiswa Magister Hukum Universitas Bandar Lampung, oktavianuspn@gmail.com

2 Dosen Pascasarjana Magister Hukum Universitas Bandar Lampung, zainab@ubl.ac.id

3 Dosen Pascasarjana Magister Hukum Universitas Bandar Lampung,

4 Jan Remmelink, 2003, Hukum Pidana: Komentar atas Pasal-Pasal Terpenting dari Kitab Undang-Undang Hukum Pidana Belanda dan Padanannya dalam Kitab Undang-Undang Hukum Pidana Indonesia. Gramedia. Jakarta, hlm. 12 
bahwa penyitaan adalah serangkaian tindakan penyidik untuk mengambil alih dan atau menyimpan di bawah penguasaannya benda bergerak atau tidak bergerak, berwujud atau tidak berwujud untuk kepentingan pembuktian dalam penyidikan, penunjukkan dan peradilan.

Barang sitaan adalah barang bukti yang telah memperoleh kekuatan hukum tetap, dirampas untuk negara dan menjadi barang rampasan negara yang selajutnya dieksekusi oleh Kejaksaan dengan cara: ${ }^{5}$
a. Dimusnahkan.
b. Dibakar sampai habis.
c. Ditenggelamkan ke dasar laut sehingga tidak bisa diambil lagi.
d. Ditanam di dalam tanah.
e. Dirusakkan sampai tidak dapat dipergunakan lagi.
f. Dilelang untuk Negara.
g. Diserahkan kepada instansi yang ditetapkan untuk dimanfaatkan.
h. Disimpan di Rupbasan untuk barang bukti dalam perkara lain

Salah satu barang rampasan negara yang dieksekusi oleh Kejaksaan Negeri Bandar Lampung dengan cara lelang adalah satu unit kendaraan bermotor roda dua sebagaimana terdapat dalam Kutipan Risalah Lelang Nomor: 908/2016 yang diterbitkan oleh Kantor Pelayanan Kekayaan Negara dan Lelang (KPKNL) Bandar Lampung. Tempat lelang dilaksanakan di Kantor Kejaksaan Negeri Bandar Lampung yang beralamat di Jalan WR Supratman Nomor 26 teluk Betung Bandar Lampung dengan Pejabat Lelang bernama Ari Tri Hermawan, SE. Penjualan lelang tersebut dilaksanakan atas permohonan Rus'an, S.H., M.H., selaku Kepala Sub Bagian Pembinaan Kejaksaan Negeri Bandar Lampung dengan surat permohonan Nomor: B521/N.8.10/Cu.1/11/2016 tanggal 3 November 2016, dengan jenis lelang yaitu lelang Eksekusi Barang Rampasan Negara. Pejabat penjual Barang Rampasan Negara tersebut adalah Rus'an, S.H., M.H., selaku Kepala Sub Bagian Pembinaan Kejaksaan Negeri Bandar Lampung dengan Surat Tugas Pejabat Penjual Nomor: PRINT-3880a/N.8.10/Cu.1/8/2016 tanggal 23 Agustus 2016. Adapun objek lelang yang terjual adalah 1 (satu) unit sepeda motor Honda Beat Pop warna hitam Nomor Polisi: BE 7396 RW nomor rangka MH17 119 FK 076071 dan nomor mesin tidak ada. Barang tersebut tidak dilengkapi surat atau bukti kepemilikan Surat Tanda Nomor Kendraan (STNK) dan Bukti Pemilik Kendaraan Bermotor (BPKB) hal ini didasarkan pada surat pernyataan dari penjual tanggal 17 November 2016. Pembeli atau pemenang lelang Barang Rampasan Negara berupa sepeda motor tersebut adalah Satria Nugraha dengan harga pembelian Rp. 2.220.000 (dua juta dua ratus dua puluh ribu rupiah), selanjutnya kepada pemenang tersebut diberikan Kutipan Risalah Lelang Nomor: 908/2016 yang berfungsi sebagai akta jual beli.

Isu hukum yang melatarbelakangi penelitian ini adalah pemenang lelang setelah mendapatkan sepeda motor tersebut tidak dapat mengurus dokumen sebagai bukti kepemilikan, baik bukti kepemilikan Surat Tanda Nomor Kendaraan (STNK) dan Bukti Pemilik Kendaraan Bermotor (BPKB), sehingga dalam hal ini menjadi kendala tersendiri bagi pemenang lelang dalam hal mengendarai sepeda

5 Basmanizar, 1997, Penyelamatan dan Pengamanan Benda Sitaan Negara dan Barang Rampasan Negara di Rumah Penyimpanan Benda Sitaan Negara. Rajawali Press. Jakarta. hlm. 4 
motor di jalan raya, sebab setiap orang yang mengemudikan kendaraan bermotor yang tidak dapat memperlihatkan Surat Izin Mengemudi (SIM), STNK yang sah atau tanda bukti lainnya yang diwajibkan menurut ketentuan perundangundangan lalu lintas jalan atau ia dapat memperlihatkan tetapi masa berlakunya telah kadaluarsa sebagaimana diatur dalam Pasal 211 KUHAP Undang-Undang Nomor 22 Tahun 2009 tentang Lalu Lintas dan Angkutan Jalan. Kendala lain yang dihadapi pemenang lelang adalah tidak dimilikinya BPKB sebagai bukti kepemilikan yang sah atas sepeda motor yang diperoleh dari hasil lelang eksekusi barang rampasan negara tersebut, sedangkan pada sisi lain penerbitan BPKB merupakan amanat Undang-Undang Nomor 22 Tahun 2009 tentang Lalu Lintas dan Angkutan Jalan merupakan bagian integral dari registrasi dan identifikasi kendaraan bermotor. Menurut Pasal 64 Undang-Undang Nomor 22 Tahun 2009 dinyatakan bahwa setiap Kendaraan Bermotor wajib diregistrasikan. Registrasi tersebut meliputi Registrasi Kendaraan Bermotor baru, Registrasi perubahan identitas Kendaraan Bermotor dan pemilik, Registrasi perpanjangan Kendaraan Bermotor; dan/atau registrasi pengesahan Kendaraan Bermotor.

Sehubungan dengan hal tersebut maka diperlukan suatu mekanisme perlindungan hukum terhadap pemenang lelang barang rampasan negara berupa kendaraan roda dua yang dieksekusi dengan cara lelang oleh Kejaksaan, khususnya dalam hal tersedianya instrumen hukum bagi pemenang untuk mengurus dokumen kepemilikan kendaraan baik berupa STNK dan BPKB, sehingga pemenang lelang memiliki kepastian hukum atas kendaraan roda dua yang diperolehnya dari proses lelang yang dilaksanakan oleh Kejaksaan tersebut.Berdasarkan uraian latar belakang di atas, maka permasalahan dalam penelitian ini dirumuskan sebagai berikut: Bagaimanakah perlindungan hukum terhadap pemenang lelang barang rampasan negara berupa kendaraan roda dua yang dieksekusi dengan cara lelang oleh Kejaksaan dalam Kutipan Risalah Lelang Nomor: 908/2016 Kejari Bandar Lampung? Bagaimanakah kepastian hukum terhadap pemenang lelang barang rampasan negara berupa kendaraan roda dua yang dieksekusi dengan cara lelang oleh Kejaksaan dalam Kutipan Risalah Lelang Nomor: 908/2016 Kejari Bandar Lampung?

Metode penelitian yang digunakan adalah yuridis normatif dan empiris. Prosedur pengumpulan data dilakukan dengan studi pustaka dan studi lapangan. Data yang diperoleh selanjutnya dianalisis secara yuridis kualitatif. Hasil penelitian ini dideskripsikan dalam bentuk penjelasan dan uraian kalimat yang mudah dibaca dan dimengerti untuk diinterprestasikan dan ditarik kesimpulan secara umum yang didasarkan fakta-fakta yang bersifat khusus terhadap pokok bahasan yang diteliti

\section{PEMBAHASAN}

A. Perlindungan Hukum terhadap Pemenang Lelang Barang Rampasan Negara Berupa Kendaraan Roda Dua yang Dieksekusi dengan Cara Lelang oleh Kejaksaan.

Kejaksaan Negeri Bandar Lampung melaksanakan eksekusi terhadap barang rampasan negara yang telah diputus oleh pengadilan, memiliki kekuatan hukum tetap dan mengikat. Eksekusi tersebut dilaksanakan terhadap satu unit kendaraan bermotor roda dua sebagaimana terdapat dalam Kutipan Risalah 
Lelang Nomor: 908/2016 yang diterbitkan oleh Kantor Pelayanan Kekayaan Negara dan Lelang (KPKNL) Bandar Lampung. Tempat lelang dilaksanakan di Kantor Kejaksaan Negeri Bandar Lampung yang beralamat di Jalan WR Supratman Nomor 26 teluk Betung Bandar Lampung dengan Pejabat Lelang bernama Ari Tri Hermawan, SE. Penjualan lelang tersebut dilaksanakan atas permohonan Rus'an, S.H., M.H., selaku Kepala Sub Bagian Pembinaan Kejaksaan Negeri Bandar Lampung dengan surat permohonan Nomor: B521/N.8.10/Cu.1/11/2016 tanggal 3 November 2016, dengan jenis lelang yaitu lelang Eksekusi Barang Rampasan Negara.

Pejabat penjual Barang Rampasan Negara tersebut adalah Rus'an, S.H., M.H., selaku Kepala Sub Bagian Pembinaan Kejaksaan Negeri Bandar Lampung dengan Surat Tugas Pejabat Penjual Nomor: PRINT-3880a/N.8.10/Cu.1/8/2016 tanggal 23 Agustus 2016. Adapun objek lelang yang terjual adalah 1 (satu) unit sepeda motor Honda Beat Pop warna hitam Nomor Polisi: BE 7396 RW nomor rangka MH17 119 FK 076071 dan nomor mesin tidak ada. Barang tersebut tidak dilengkapi surat atau bukti kepemilikan Surat Tanda Nomor Kendraan (STNK) dan Bukti Pemilik Kendaraan Bermotor (BPKB) hal ini didasarkan pada surat pernyataan dari penjual tanggal 17 November 2016. Pembeli atau pemenang lelang Barang Rampasan Negara berupa sepeda motor tersebut adalah Satria Nugraha dengan harga pembelian Rp. 2.220.000 (dua juta dua ratus dua puluh ribu rupiah), selanjutnya kepada pemenang diberikan Kutipan Risalah Lelang Nomor: 908/2016 yang berfungsi sebagai akta jual beli.

Proses eksekusi barang rampasan negara oleh Kejaksaan Negeri Bandar Lampung tersebut telah sesuai dengan peraturan perundang-undangan yang berlaku, dasar hukumnya adalah Pasal 30 Ayat (1) huruf (b) Undang-Undang Kejaksaan bahwa dalam bidang pidana, kejaksaan mempunyai tugas dan wewenang melaksanakan penetapan hakim dan putusan pengadilan yang telah memperoleh kekuatan hukum tetap. Prosedur eksekusi putusan pengadilan oleh Kejaksaan sebagaimana diatur dalam Pasal 270 Kitab Undang-Undang Hukum Acara Pidana (KUHAP), yaitu penitera mengirimkan salinan Putusan Pengadlan kepada jaksa. Eksekusi putusan pengadilan baru dapat dilakukan oleh jaksa, setelah jaksa menerima salinan surat putusan dari panitera. Adapun batas waktu pengiriman salinan putusan dari Panitera kepada jaksa untuk perkara acara biasa paling lama 1 (satu) minggu dan untuk perkara dengan acara singkat paling lama 14 hari.

Barang sitaan sebagai barang bukti tersebut dapat menjadi barang rampasan, sebagaimana dinyatakan dalam Pasal 1 Kitab Undang-Undang Hukum Pidana, bahwa barang kepunyaan terhukum yang diperoleh dengan kejahatan atau sengaja dipakai untuk melakukan kejahatan dapat dirampas untuk negara. Barang sitaan yang digunakan sebagai barang bukti dalam perkara pidana, dapat menjadi barang rampasan Kejaksaan, jika terdapat beberapa unsur yang dipenuhi oleh hakim untuk dapat merampas suatu barang, yaitu barang sitaan itu kepunyaan terhukum yang diperoleh dengan kejahatan atau sengaja dipakai untuk melakukan kejahatan.

Berdasarkan hasil wawancara kepada Rus'an selaku Kepala Sub Bagian Pembinaan Kejaksaan Negeri Bandar Lampung diketahui bahwa barang sitaan itu dapat menjadi barang rampasan, maka barang tersebut haruslah merupakan 
barang kepunyaan pelaku, jika barang sitaan itu dipergunakan oleh terpidana untuk melakukan tindak pidana atau hasil dari tindak pidana akan tetapi barang tersebut bukanlah milik terpidana, maka atas barang tersebut tidak dapat dirampas tetapi hanya sebagai barang bukti dan harus dikembalikan kepada yang berhak, kecuali dalam hal pemalsuan uang sebagaimana diatur dalam Pasal 250 KUHP.

Pelaksanaan putusan terhadap barang bukti dilakukan berdasarkan amar putusan pengadilan, dapat dikembalikan kepada yang berhak yang namanya tercamtum dalam putusan. Sebelum putusan pengadilan memperoleh kekuatan tetap. Dalam Pasal 194 Ayat (2) KUHAP disebutkan bahwa kekucuali apabila terdapat alasan yang sah pengadilan menetapkan supaya barang bukti diserahkan segera sesudah sidang selesai. Dalam penjelasan Ayat (2) dari Pasal 194 KUHAP ditegaskan bahwa penetapan mengenai penyerahan barang tersebut misalnya sangat diperlukan untuk mencari nafkah. Dalam hal penyerahan barang bukti diserahkan sebelum putusan mempunyai kekuatan tetap, maka harus disertai dengan syarat tertentu antara lain barang tersebut setiap waktu dihadapkan ke pengadilan dalam keadaan utuh (Pasal 194 Ayat (3) KUHAP dan penjelasannya).

Tenggang waktu untuk menyelesaikan barang rampasan selambatlambatnya 4 (empat) bulan setelah putusan Pengadilan memperoleh kekuatan hukum tetap (Pasal 4). Barang rampasan yang telah diputus oleh Pengadilan dilimpahkan penanganannya kepada Bidang yang berwenang menyelesaikan barang rampasan sesegera mungkin setelah keputusan Pengadilan memperoleh kekuatan hukum tetap, dengan menyertakan salinan vonis dan pendapat hukum. Setelah menerima barang rampasan, bidang yang berwenang menyelesaikan barang rampasan mengajukan permohonan kepada Kepala Kejaksaan Negeri atau Kepala Kejaksaan Tinggi atau Jaksa Agung Muda yang berwenang menyelesaikan barang rampasan.

Berdasarkan hasil wawancara kepada Rus'an selaku Kepala Sub Bagian Pembinaan Kejaksaan Negeri Bandar Lampung diketahui bahwa setiap barang rampasan yang akan dijual lelang oleh Kejaksaan terlebih dahulu mendapat izin dari Kepala Kejaksaan Negeri atau Kepala Kejaksaan Tinggi atau Jaksa Agung Muda yang berwenang menyelesaikan barang rampasan, menurut harga dan barang rampasan yang dikeluarkan oleh Instansi yang berwenang. Setelah proses lelang dilaksanakan sesuai dengan peraturan perundang-undangan yang berlaku maka barang rampasan negara berupa sepeda motor tersebut beralih hak kepemilikannya kepada pemenang lelang. Selanjutnya pemenang lelang tentuanya menghendaki adanya dokumen kepemilikan yang sah baik berupa Surat Tanda Nomor Kendaraan (STNK) dan Bukti Pemilik Kendaraan Bermotor (BPKB) atas kendaraan yang diperolehnya dari proses lelang. Hal ini sesuai dengan Pasal 211 KUHAP Undang-Undang Nomor 22 Tahun 2009 tentang Lalu Lintas dan Angkutan Jalan bahwa setiap orang yang mengemudikan kendaraan bermotor yang tidak dapat memperlihatkan Surat Izin Mengemudi (SIM), STNK yang sah atau tanda bukti lainnya yang diwajibkan menurut ketentuan perundang-undangan lalu lintas jalan atau ia dapat memperlihatkan tetapi masa berlakunya telah kadaluarsa.

Menurut penjelasan Satria Nugraha selaku Pemenang Lelang maka diketahui bahwa setelah mendapatkan sepeda motor tersebut ia tidak dapat 
mengurus dokumen sebagai bukti kepemilikan, baik bukti kepemilikan Surat Tanda Nomor Kendaraan (STNK) dan Bukti Pemilik Kendaraan Bermotor (BPKB), sehingga dalam hal ini menjadi kendala tersendiri baginya dalam hal mengendarai sepeda motor di jalan raya, misalnya merasa tidak aman dan nyaman ketika mengendarai sepeda motor tersebut di jalan raya karena tidak dilengkapi dengan STNK.

Berdasarkan hasil wawancara kepada Reza Khomeini selaku Kasatlantas Polresta Bandar Lampung diketahui bahwa pemberlakuan Undang-Undang Nomor 22 Tahun 2009 tentang Lalu Lintas dan Angkutan Jalan pada dasarnya bertujuan untuk mewujudkan pelayanan lalu lintas dan Angkutan jalan yang aman, selamat, tertib, lancar, dan terpadu dengan moda angkutan lain untuk mendorong perekonomian nasional, memajukan kesejahteraan umum, memperkukuh persatuan dan kesatuan bangsa, serta mampu menjunjung tinggi martabat bangsa. Selain itu untuk mewujudkan etika berlalu lintas dan budaya bangsa dan mewujudkan penegakan hukum dan kepastian hukum bagi masyarakat.

Menurut penjelasan Satria Nugraha selaku Pemenang Lelang maka diketahui bahwa selain tidak dapat mengurus STNK, sebagai pemenang lelang barang rampasan negara berupa sepeda motor, ia juga tidak dapat mengurus Bukti Pemilik Kendaraan Bermotor (BPKB). Dengan demikian pemenang lelang merasa kurang nyaman memiliki sepeda motor dari hasil lelang tanpa dilengkapi dengan dokumen kepemilikan yang sah. Satu-satu dokumen yang dimilikinya atas sepeda motor tersebut adalah Risalag Lelang.

Berdasarkan hasil wawancara kepada Reza Khomeini selaku Kasatlantas Polresta Bandar Lampung diketahui bahwa penerbitan BPKB merupakan amanat Undang- Undang Nomor 22 Tahun 2009 tentang Lalu Lintas dan Angkutan Jalan merupakan bagian integral dari registrasi dan identifikasi kendaraan bermotor. Menurut Pasal 64 Undang-Undang Nomor 22 Tahun 2009 dinyatakan bahwa setiap Kendaraan Bermotor wajib diregistrasikan. Registrasi tersebut meliputi Registrasi Kendaraan Bermotor baru, Registrasi perubahan identitas Kendaraan Bermotor dan pemilik, Registrasi perpanjangan Kendaraan Bermotor; dan/atau registrasi pengesahan Kendaraan Bermotor. Berdasarkan hasil wawancara kepada Koimah Indraguru selaku Kepala UPTD Wilayah I Bandar Lampung/Samsat Bandar Lampung diketahui bahwa Tugas pokok Samsat Bandar Lampung adalah melaksanakan pelayanan kepada masyarakat secara terpadu dan terkoordinasi meliputi Tata Laksana Pendaftaran Kendaraan Bermotor, Tata Laksana Pemungutan PKB dan BBN-KB sesuai dengan peraturan perpajakan yang berlaku dan Tata Laksana Pemungutan SWDKLLJ.

Berdasarkan uraian di atas maka diketahui bahwa pemenang lelang barang rampasan negara berupa kendaraan bermotor roda dua (sepeda motor) tidak dapat memiliki bukti kepemilikian yang sah atas sepeda motor yang dimilikinya, sehingga tidak dapat memenuhi ketentuan yang diatur dalam Undang-Undang Lalu Lintas dan Angkutan Jalan. Ketertiban lalu lintas dapat dicapai apabila semua masyarakat sudah memiliki pandangan yang sama tentang pentingnya penerapan Undang-Undang Lalu lintas. Sehubungan dengan hal tersebut maka diperlukan suatu mekanisme perlindungan hukum terhadap pemenang lelang barang rampasan negara berupa kendaraan roda dua yang dieksekusi dengan cara lelang 
oleh Kejaksaan, khususnya dalam hal tersedianya instrumen hukum bagi pemenang untuk mengurus dokumen kepemilikan kendaraan baik berupa STNK dan BPKB, sehingga pemenang lelang memiliki kepastian hukum atas kendaraan roda dua yang diperolehnya dari proses lelang yang dilaksanakan oleh Kejaksaan tersebut.

Fitzgerald menjelaskan teori pelindungan hukum Salmond bahwa hukum bertujuan mengintegrasikan dan mengkoordinasikan berbagai kepentingan dalam masyarakat karena dalam suatu lalu lintas kepentingan, perlindungan terhadap kepentingan tertentu hanya dapat dilakukan dengan cara membatasi berbagai kepentingan di lain pihak. Kepentingan hukum adalah mengurusi hak dan kepentingan manusia, sehingga hukum memiliki otoritas tertinggi untuk menentukan kepentingan manusia yang perlu diatur dan dilindungi. Perlindungan hukum harus melihat tahapan yakni perlindungan hukum lahir dari suatu ketentuan hukum dan segala peraturan hukum yang diberikan oleh masyarakat yang pada dasarnya merupakan kesepakatan masyarakat tersebut untuk mengatur hubungan prilaku antara anggota-anggota masyarakat dan antara perseorangan dengan pemerintah yang dianggap mewakili kepentingan masyarakat. ${ }^{3}$

Pemenang lelang barang rampasan negara berupa kendaraan roda dua yang dieksekusi dengan cara lelang oleh Kejaksaan, secara ideal seharusnya memperoleh perlindungan hukum berupa adanya peraturan hukum atau peraturan perundang-undangan yang memungkinkannya untuk mengurus dan memiliki dokumen kepemilikan kendaraan baik berupa STNK dan BPKB, sehingga haknya sebagai pemenang lelang dapat terpenuhi.

\section{B. Kepastian Hukum terhadap Pemenang Lelang Barang Rampasan Negara Berupa Kendaraan Roda Dua yang Dieksekusi Dengan Cara Lelang oleh Kejaksaan.}

Pemenang lelang barang rampasan negara berupa kendaraan roda dua yang dieksekusi dengan cara lelang oleh Kejaksaan, tidak memperoleh kepastian hukum atas kepemilikan kendaraannya yang diperoleh dari memenangkan lelang, karena pemenang lelang tidak dapat mengurus dan memiliki dokumen kepemilikan kendaraan baik berupa STNK dan BPKB. Hukum yang berkualitas pada dasarnya merupakan praktik hukum yang mengandung nilai-nilai keadilan bagi seluruh masyarakat dan sesuai dengan kehendak atau aspirasi masyarakat, sebab itu hukum yang baik akan menjamin kepastian hak dan kewajiban secara seimbang kepada tiap-tiap orang. Tujuan hukum, di samping menjaga kepastian hukum juga menjaga sendi-sendi keadilan yang hidup dalam masyarakat. Hal utama bagi kepastian hukum yakni, adanya peraturan itu sendiri. tentang apakah peraturan itu harus adil dan mempunyai kegunaan bagi masyarakatnya, adalah di luar pengutamaan nilai kepastian hukum.

Pentingnya faktor perundang-undangan sebagai dasar hukum sesuai dengan karakter hukum positif dalam wujudnya sebagai peraturan peraturan perundang-undangan, di samping ditentukan oleh suasana atau konfigurasi politik momentum pembuatannya, juga berkaitan erat dengan komitmen moral serta profesional dari para anggota legislatif itu sendiri. Oleh karena semangat hukum yang dibangun berkaitan erat dengan visi pembentuk undang-undang, 
maka dalam konteks membangun hukum yang demokratis, tinjauan tentang peran pembentuk undang-undang penting dilakukan. Pembentuk undang-undang tidak semata-mata berkewajiban mengadaptasikan hukum untuk mengubah masyarakat menjadi lebih baik, tetapi juga memiliki kesempatan untuk memberikan sumbangan terhadap pembentukan perubahan masyarakat itu sendiri. Pembentuk undang-undang, dengan demikian, tidak lagi semata-mata mengikuti perubahan masyarakat, akan tetapi justru mendahului perubahan masyarakat itu. Masyarakat yang adil dan makmur serta modern yang merupakan tujuan pembangunan bangsa, justru sesungguhnya merupakan kreasi tidak langsung dari pembentuk undang-undang.

Peraturan perundang-undangan sebagai instrumen hukum pidana menciptakan tata tertib di dalam masyarakat melalui pemberian pidana kepada para pelaku kejahatan, artinya dengan ditetapkannya di dalam undang-undang perbuatan-perbuatan tertentu sebagai perbuatan yang dilarang disertai ancaman pidana, atau dengan ditetapkannya perbuatan-perbuatan tertentu sebagai tindak pidana di dalam undang-undang, maka diharapkan warga masyarakat akan mengerti dan menyesuaikan diri sehingga tidak melakukan perbuatan-perbuatan yang telah dilarang dan diancam pidana itu. Tidak tersedianya instrumen hukum bagi pemenang lelang barang rampasan negara berupa kendaraan roda dua yang dieksekusi dengan cara lelang oleh Kejaksaan untuk mengurus dan memiliki dokumen kepemilikan kendaraan baik berupa STNK dan BPKB, menunjukkan adanya kekosongan hukum dalam ini, sehingga diperlukan adanya diskresi dari pejabat yang berwenang maupun aparat penegak hukum dalam hal mendapati peristiwa hukum tersebut.

Pejabat yang berwenang maupun aparat penegak hukum memiliki kebebasan bertindak atau mengambil keputusan berdasarkan pendapat sendiri dalam hal tidak adanya instrumen hukum. Diskresi diperlukan sebagai pelengkap asas legalitas, yaitu asas hukum yang menyatakan bahwa setiap tindakan atau kebijakan harus berdasarkan ketentuan undang-undang, akan tetapi tidak mungkin bagi undang-undang untuk mengatur segala macam hal dalam praktek kehidupan sehari-hari. Oleh sebab itu diperlukan adanya kebebasan atau diskresi pada pejabat publik dalam melaksanakan tugas, fungsi dan kewajiban yang dibebankan kepadanya.Sehingga dapat dikatakan bahwa untuk mengatur hal-hal yang lebih rinci dari pelaksanaan suatu ketentuan undang-undang, pemerintah atau dalam hal ini pejabat publik diberikan kebebasan untuk mengambil keputusan berdasarkan pendapat sendiri, namun ini tidak berarti tidak ada rambu-rambu atau koridor-koridor hukum yang membatasinya. Adanya payung hukum bagi pemenang lelang barang rampasan negara berupa kendaraan roda dua yang dieksekusi dengan cara lelang oleh kejaksaan dalam mengurus dan memiliki bukti kepemilikan kendaraan bermotor secara legal maka akan memberikan kepastian hukum bagi pemenang lelang. 


\section{PENUTUP}

\section{A. Kesimpulan}

Berdasarkan hasil penelitian dan pembahasan maka dapat disimpulkan sebagai berikut:

1. Perlindungan Hukum terhadap pemenang lelang barang rampasan negara berupa kendaraan roda dua yang dieksekusi dengan cara lelang oleh Kejaksaan dalam Kutipan Risalah Lelang Nomor: 908/2016 dapat diwujudkan dengan memberlakukan suatu peraturan perundangundangan atau kebijakan khusus dalam rangka memenuhi hak pemenang lelang untuk mengurus dan memiliki dokumen kepemilikan kendaraan baik berupa STNK dan BPKB, sehingga pemenang memiliki dasar hukum yang kuat atas kepemilikan sepeda motor tersebut.

2. Kepastian Hukum terhadap pemenang lelang barang rampasan negara berupa kendaraan roda dua yang dieksekusi dengan cara lelang oleh Kejaksaan belum terwujud karena pemenang lelang tidak dapat mengurus dan memiliki dokumen kepemilikan kendaraan baik berupa STNK dan BPKB. Pemenang lelang dalam hal ini hanya menerima Kutipan Risalah Lelang Nomor: 908/2016 yang berfungsi sebagai akta jual beli.

\section{B. Saran}

Saran dalam penelitian ini adalah sebagai berikut:

1. Hendaknya pemerintah atau instansi terkait memberlakukan suatu peraturan perundang-undangan atau kebijakan khusus dalam rangka memenuhi hak pemenang lelang untuk mengurus dan memiliki dokumen kepemilikan kendaraan baik berupa STNK dan BPKB, sehingga pemenang memiliki dasar hukum yang kuat atas kepemilikan sepeda motor tersebut.

2. Hendaknya masyarakat sebagai pemenang lelang disarankan untuk terus menempuh upaya untuk memperoleh perlindungan atas kepemilikan kendaraan yang didapat dari hasil lelang mengingat adanya dokumen kepemilikan kendaraan baik berupa STNK dan BPKB merupakan kepastian hukum atas kepemilikan kendaraan bermotor. 


\section{DAFTAR PUSTAKA}

Barda Nawawi Arief, 2003, Bunga Rampai Kebijakan Hukum Pidana, Citra Aditya Bakti. Bandung.

Basmanizar, 1997, Penyelamatan dan Pengamanan Benda Sitaan Negara dan Barang Rampasan Negara di Rumah Penyimpanan Benda Sitaan Negara. Rajawali Press. Jakarta.

Hendrastanto, 1997. Kapita Selekta Hukum Acara Pidana di Indonesia. Bina Aksara, Jakarta.

Idwan Santoso, 1997, Manajemen Lalu-Lintas Perkotaan, Badan Penerbit ITB, Bandung.

Jan Remmelink, 2003, Hukum Pidana: Komentar atas Pasal-Pasal Terpenting dari Kitab Undang-Undang Hukum Pidana Belanda dan Padanannya dalam Kitab Undang-Undang Hukum Pidana Indonesia. Gramedia.

Mardjono Reksodiputro, 1994, Sistem Peradilan Pidana Indonesia (Melihat Kejahatan dan Penegakan Hukum dalam Batas-Batas Toleransi) Pusat Keadilan dan Pengabdian Hukum. Jakarta.

Mochtar Kusumaatmaja, 2006, Konsep-konsep Hukum dalam Pembangunan, Alumni, Bandung.

Mukhlis, 2009, Sistem Manajemen Transportasi Kota, Print Offset. Jakarta.

Nikolas, 2009, Acara Pidana Indonesia dalam Sirkus Hukum. Ghalia Indonesia, Bogor

Noor Kolim. 2005. Pokok-Pokok Pengelolaan Benda Sitaan dan Barang Rampasan Negara di Rupbasan, Pusdiklat Pegawai Depertemen Hukum dan HAM RI. Jakarta

Phillipus M. Hadjon, 1987. Perlindungan Hukum Bagi Rakyat Indonesia, Bina Ilmu, Surabaya.

R. Badri, 2005, Hak dan Kewajiban dalam Berlalu Lintas. Admin, Surabaya.

Ratna Nuru Alfiah, 2001, Benda Sitaan dan Rampasan Negara, Rineka Cipta,

Jakarta. Satjipto Raharjo, 2000, Ilmu Hukum, Citra Aditya Bakti, Bandung.

---------, 2006, Hukum Dalam Jagad Ketertiban. UKI Press, Jakarta. 
Soerjono Soekanto, 1983, Pengantar Penelitian Hukum, Rineka Cipta, Jakarta.

--------, 1990, Polisi dan Lalu Lintas Analisis Menurut Sosiologi Hukum. Mandar Maju, Bandung.

Sudarto, 1983, Kapita Selekta Hukum Pidana, Alumni, Bandung.

Sudikno Mertokusumo, 2009, Penemuan Hukum, Citra Aditya Bakti,

Theo Huijbers, 1995, Filsafat Hukum, Penerbit Kanisius, Yogyakarta.

Wiryono Prodjodikoro, 1990, Hukum Acara Pidana di Indonesia, Sumur Simanjuntak, Bandung.

Zainab Ompu Jainah. 2018., Kapita Selekta Hukum Pidana. Tira Smart. Tangerang.

Undang-Undang Dasar Negara Republik Indonesia Hasil Amandemen Keempat Tahun 2002

Undang-Undang Nomor 1 Tahun 1946 jo. Undang-Undang Nomor 73 Tahun 1958 tentang Pemberlakuan Kitab Undang-Undang Hukum Pidana.

Undang-Undang Nomor 16 Tahun 2004 tentang Kejaksaan Republik Indonesia.

Undang-Undang Nomor 22 Tahun 2009 tentang Lalu Lintas dan Angkutan Jalan Peraturan Pemerintah Nomor 58 Tahun 2010 tentang Perubahan Atas

Peraturan Pemerintah Nomor 27 Tahun 1983 tentang Pelaksanaan Kitab

Undang- Undang Hukum Acara Pidana

Keputusan Jaksa Agung Republik Indonesia Nomor KEP-089/J.A/8/1988 tentang Penyelesaian Barang Rampasan

Peraturan Direktorat Jenderal Kekayaan Negara Nomor 6/KN/2013 tentang Petunjuk Pelaksanaan Lelang 


\section{PEDOMAN PENULISAN \\ JURNAL PRANATA HUKUM}

1. Naskah bersifat orisinil, baik berupa hasil riset atau tinjauan atas suatu permasalahan hukum yang berkembang di masyarakat (artikel lepas), dimungkinkan juga tulisan lain yang dipandang memberikan kontribusi bagi pengembangan ilmu hukum.

2. Penulisan terdiri atas beberapa bab penulisan hasil penelitian terdiri dari $3 \mathrm{BAB}$, yaitu ;

BAB I. PENDAHULUAN (Latar Belakang dan Rumusan Masalah) BAB II. PEMBAHASAN (Kerangka Teori dan Analisis), dan BAB III. PENUTUP (Kesimpulan dan Saran).

3. Tulisan menggunakan bahasa indonesia maupun bahasa inggris yang memenuhi kaidah bahasa yang baik dan benar,tulisan menggunakan bahasa indonesia disertai abstrak dalam bahasa inggris (200 kata) dan Kata kunci, ketentuan ini berlaku sebaliknya.

4. Setiap kutipan harus menyebutkan sumbernya dengan format footnote. Sumber kutipan harus memuat nama pengarang, tahun penerbitan, judul buku, nama penerbit, kota penerbit, dan halaman. Contoh : Bagir Manan. 1994. Hubungan Antara Pemerintah Pusat dan Daerah Menurut UUD 1945. Pustaka Sinar Harapan. Jakarta. 1994, hlm. 19. Untuk artikel dari internet dengan susunan: nama penulis, judul tulisan digaris bawah, alamat website, waktu download/unduh.

5. Naskah harus disertai dengan daftar pustaka atau referensi ,terutama yang digunakan sebagai bahan acuan langsung. Daftar pustaka dan referensi bersifat alfabetis dengan format; nama pengarang, judul buku, nama penerbit, kota terbit, dan tahun penerbitan. Contoh: Bagir Manan. 1994. Hubungan Antara Pemerintah Pusat dan Daerah Menurut UUD 1945. Pustaka Sinar Harapan. Jakarta.

6. Panjang tulisan antara 15-25 halaman, font cambria dengan 1,15 spasi. Dalam hal hal tertentu berlaku pengecualian panjang tulisan.

7. Naskah disertai nama lengkap penulis, alamat e-mail dan lembaga tempat berafiliasi saat ini, dan hal lain yang dianggap penting. 
Jurnal PRANATA HUKUM dimaksudkan sebagai media komunikasi, edukasi, dan informasi ilmiah bidang ilmu hukum khususnya, dan ilmu sosial pada umumnya. Sajian dan kemasan diupayakan komunikatif melalui bahasa ilmiah.

Redaksi mengundang semua elemen masyarakat baik civitas akademika, praktisi, lembaga masyarakat, maupun perorangan yang berminat terhadap bidang hukum untuk berpartisipasi mengembangkan gagasan, wawasan, dan pengetahuan melalui tulisan untuk dimuat dalam jurnal ini.

Melalui PRANATA HUKUM diharapkan terjadi proses pembangunan dan pengembangan bidang hukum sebagai bagian penting dari rangkaian panjang proses memajukan masyarakat bangsa.
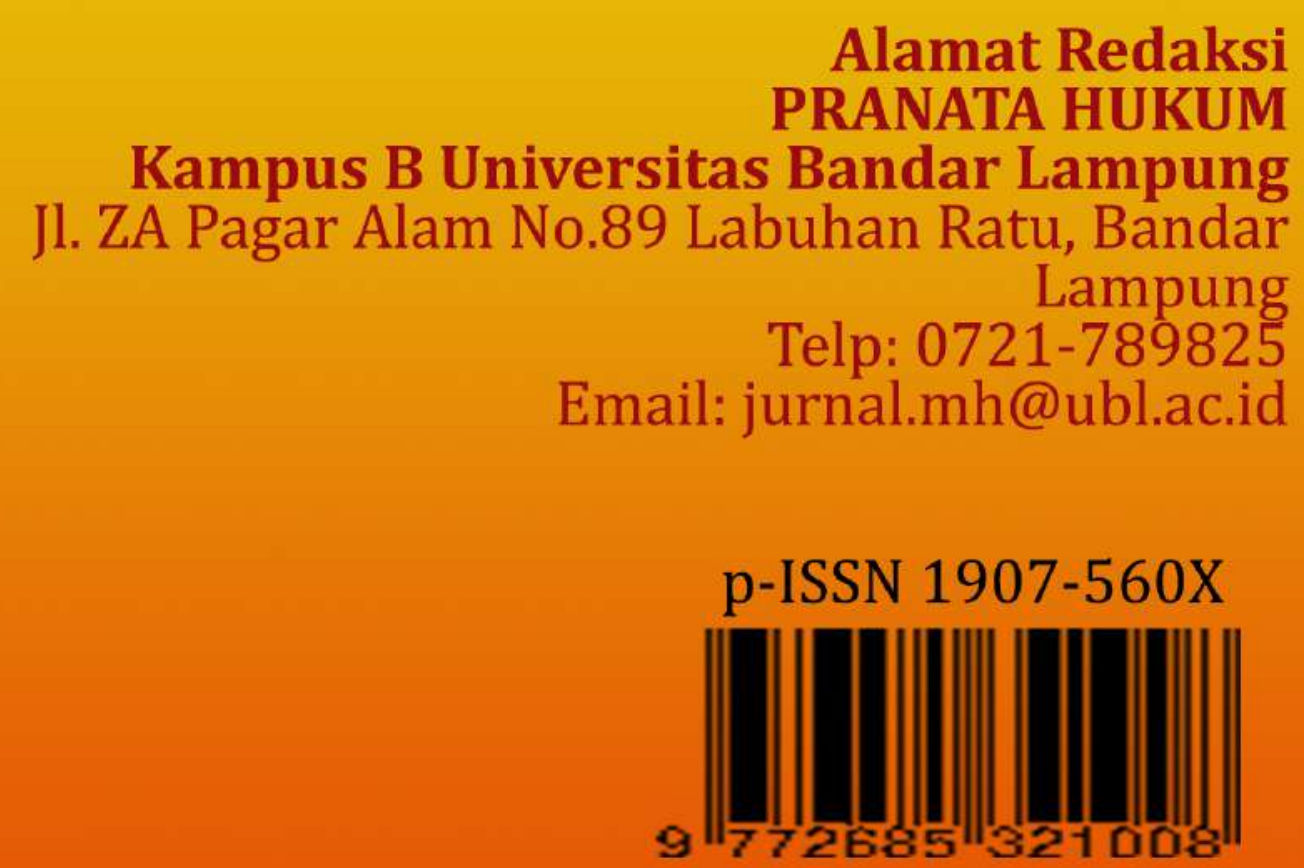